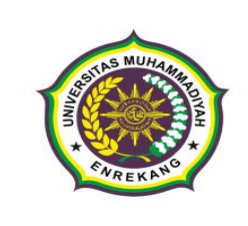

Vol. 5 - No. 1, year (2021), page 51 - 57

| ISSN 2548-8201 (Print)| 2580-0469) (Online)|

\title{
Hasil Belajar Biologi Siswa yang Dibelajarkan Dengan Menerapkan Metode Pembelajaran Improve Dan Ekspositori
}

\author{
Firdaus $^{1 *}$, Rasydianah ${ }^{2}$ \\ ${ }^{1}$ (Prodi Pendidikan Biologi FKIP, Universitas Sulawesi Barat, Indonesia) \\ ${ }^{2}$ (Madrasah Tsanawiyah Negeri 2 Majene, Indonesia) \\ * Corresponding Author. E-mail: ${ }^{1}$ firdaus@unsulbar.ac.id
}

\begin{abstract}
Receive: $12 / 02 / 2020$
Accepted: 28/02/2021

Published: 01/03/2021

Abstrak

Penelitian ini merupakan penelitian quasi-experimental yang bertujuan untuk mengetahui perbedaan hasil belajar materi pewarisan sifat siswa kelas IX yang dibelajarkan dengan menerapkan metode pembelajaran IMPROVE dan metode pembelajaran ekspositori. Penelitian ini menggunakan pretestposttest non-equivalent comparison groups design. Populasinya adalah seluruh siswa kelas IX MTsN 2 Majene yang terdiri atas lima kelas. Sampelnya adalah siswa kelas IX.A MTsN 2 Majene yang dibelajarkan dengan menerapkan metode IMPROVE terdiri dari 22 orang dan siswa kelas IX.B MTsN 2 Majene dibelajarkan dengan menerapkan metode ekspositori yang terdiri dari 22 orang. Teknik pengumpulan data pada penelitian ini menggunakan instrumen berupa tes hasil belajar dalam bentuk pilihan ganda, isian, dan benar salah. Analisis data menggunakan statistik deskriptif dan statistik inferensial yaitu uji t. Berdasarkan hasil analisis data dapat disimpulkan bahwa, (1) Hasil belajar biologi materi pewarisan sifat siswa yang dibelajarkan dengan menerapkan metode pembelajaran IMPROVE pada kelas IX MTsN 2 Majene berada pada kategori baik; (2) Hasil belajar biologi materi pewarisan sifat siswa yang dibelajarkan dengan menerapkan metode pembelajaran ekspositori pada kelas IX MTsN 2 Majene berada pada kategori baik. (3) Tidak ada perbedaan hasil belajar biologi materi pewarisan sifat siswa yang dibelajarkan dengan menerapkan metode pembelajaran IMPROVE dan ekspositori pada kelas IX MTsN 2 Majene.
\end{abstract}

Kata Kunci: Hasil belajar, IMPROVE, dan ekspositori.

\begin{abstract}
This study was quasi-experimental research that aimed to know biological learning achievement of students in heredity matter learnt by applying IMPROVE instructional method and expository instructional method at grade IX MTsN 2 Majene. This study used pretest-posttest non-equivalent comparison groups design. The population of this study was all of grade IX MTsN 2 Majene consist of five class. The sample of this study were students of grade IX.A MTsN 2 Majene learned by applying IMPROVE instructional method that was consisting of 22 people and students of grade IX.B MTsN 2 Majene learned by applying expository instructional method that was consisting of 22 people. The data collection techniques in this study used instrument that consist of learning achievement test in multiple choice, completion test, and true false form. The data analysis techniques in this study used descriptive statistics analysis and inferential statistics analysis with t test. According to this study analysis can be concluded that (1) Biological learning achievement of students in heredity matter learnt by applying IMPROVE instructional method at class IX MTSN 2 Majene had good category; (2) Biological learning achievement of students in heredity matter learnt by applying expository instructional method at class IX MTsN 2 Majene had good category; (3) There was no the difference of biology learning achievement of students in heredity matter were learnt by applying IMPROVE instructional method and expository instructional method at grade IX MTsN 2 Majene.
\end{abstract}

Keywords: Learning achievement, IMPROVE, and exposito 



\section{PENDAHULUAN}

\section{Pendahuluan}

Pendidikan merupakan proses memanusiakan manusia. Hal ini berarti bahwa melalui pendidikan, manusia dapat menjadi manusia seutuhnya, yaitu manusia yang mengenal dirinya sendiri dan menggunakan keseluruhan dirinya untuk menjaga kedamaian berkehidupan. Pembahasan terkait pendidikan tidak terlepas dari instansi yang bernama sekolah. Sekolah merupakan suatu instansi yang bertugas untuk menciptakan lingkungan belajar bagi setiap siswa (manusia) dan bertujuan untuk menjadikan manusia tersebut berguna dan bermanfaat bagi lingkungannya. Agar tugas dan tujuan sekolah dapat tercapai sesuai dengan pengharapannya, maka beberapa hal yang selalu menjadi perhatian adalah komponen tenaga pengajar dan pendidik (guru), pelajar (siswa), dan proses belajar dan mengajar (PBM). Guru dan siswa merupakan subjek dan objek pendidikan, sementara PBM merupakan media diantara keduanya. Akhir-akhir ini, PBM merupakan komponen yang mengalami banyak inovasi. Hal ini disebabkan karena sifat PBM sebagai suatu sistem pembelajaran yang memiliki peran sentral untuk menentukan kualitas dari kedua komponen lainnya, yaitu Guru dan Siswa.

Inovasi PBM tentu saja berawal dari hasil belajar siswa yang tidak sesuai dengan harapan atau kriteria ketuntasan minimal (KKM) terhadap materi pokok suatu mata pelajaran tertentu. Dalam mata pelajaran ilmu pengetahuan alam, salah satu materi pokok yang relatif menunjukkan hasil belajar yang tidak sesuai dengan KKM adalah materi Pewarisan Sifat. Hal ini seperti yang ditunjukkan pada observasi awal penulis ke MTsN 2 Majene Kelas IX, bahwa nilai rata-rata mata pelajaran IPA materi pewarisan sifat adalah sekitar 75 padahal nilai KKMnya adalah 83.

Pewarisan Sifat merupakan materi pelajaran yang bersifat abstrak. Beberapa sub materi yang diajarkan dalam materi ini adalah DNA, Kromosom, dan Hukum
Mendel. Sub pokok tersebut merupakan materi pelajaran yang tidak dapat diamati secara langsung dalam proses belajar di sekolah, sehingga membutuhkan kemampuan berpikir yang lebih tinggi (metakognisi). "Thinking about thinking" adalah istilah ringkas untuk menggambarkan terminologi metakognisi.

Metakognisi merupakan suatu kesadaran tentang kognitif kita sendiri, bagaimana kognitif kita bekerja serta bagaimana mengaturnya. Kemampuan metakognisi ini sangat penting terutama untuk keperluan efisiensi penggunaan kognitif kita dalam menyelesaikan masalah. Salah satu penelitian mengenai kemampuan metakognisi yang telah dilakukan oleh Aurah, et al. (2014) berjudul "Genetics Problem Solving in High School Testing in Kenya: Effects of Metacognitive Prompting During Testing" menunjukkan bahwa siswa yang diajar menggunakan pendekatan metakognisi memiliki hasil belajar yang lebih baik dibandingkan dengan siswa yang tidak diajar menggunakan pendekatan metakognisi. Aurah, et al. (2014) juga menyarankan agar menggunakan metode yang mengandung pendekatan metakognisi dalam proses pembelajaran. Salah satu inovasi PMB yang menggunakan pendekatan metakognisi adalah metode pembelajaran IMPROVE (Introducing the new concepts, Metacognitive questioning, Practicing, Reviewing and reducing difficulties, Obtaining mastery, Verification, and Enrichment).

Metode pembelajaran IMPROVE merupakan salah satu metode yang memiliki tingkat kebermaknaan tinggi. Dalam metode ini, siswa dikenalkan pada suatu konsep baru, memberikan pertanyaanpertanyaan metakognitif dan kemudian berlatih memecahkan masalah terkait materi. Kemudian guru mereview kesulitankesulitan yang dialami siswa. Siswa juga dapat memverifikasi dan mengevaluasi apa yang telah mereka pelajari sehingga dapat memperkaya pengetahuan mereka (Mavarech, 1997 dalam Yuningsih, 2010). 
Metode ekspositori merupakan metode yang cenderung berpusat pada guru dimana guru aktif memberikan penjelasan atau informasi pembelajaran secara terperinci tentang materi pembelajaran. Berdasarkan observasi peneliti pada sekolah ini, mayoritas guru menggunakan metode ekspositori dalam melaksanakan proses pembelajaran tidak terkecuali guru ilmu pengetahuan alam dalam mengajarkan materi pewarisan sifat sehingga peneliti merasa bahwa penerapan metode IMPROVE perlu dibandingkan dengan metode ekspositori.

Peneliti tertarik untuk menerapkan metode IMPROVE ini pada MTsN2 Majene kelas IX. Peneliti berharap hasil belajar siswa dapat ditingkatkan serta memenuhi nilai KKM. Sebagai perbandingan pencapaian hasil belajarnya, peneliti akan membandingkan penggunaan metode IMPROVE dengan metode ekspositori.

\section{Metode}

Penelitian ini merupakan jenis penelitian Quasi-Experimental. Desain penelitian yang digunakan dalam penelitian ini adalah Pretest-posttest Non-equivalent Comparison Groups Design. Variabel bebas adalah metode pembelajaran yang terdiri atas metode IMPROVE dan metode ekspositori sedangkan variabel terikat adalah hasil belajar biologi siswa (materi pewarisan sifat).

Populasi dalam penelitian ini adalah seluruh siswa kelas IX MTsN 2 Majene yang terdiri atas lima kelas. Sampel ada dua kelas yang dipilih secara acak yaitu kelas IX.A dan IX.B. Penelitian ini dilaksanakan selama tiga minggu.

Instrumen yang digunakan dalam penelitian ini adalah instrumen tes. Instrumen tes adalah serentetan pertanyaan atau latihan. Instrumen tes yang digunakan untuk mengukur hasil belajar biologi siswa berupa soal pilihan ganda, soal benar salah, dan soal isian singkat.

Teknik pengumpulan data dilakukan dengan menggunakan tes dalam bentuk pretest posttest. Data yang dianalisis ialah nilai gain ternormalisasi yang diperoleh dari kedua kelas dengan menggunakan uji $\mathrm{t}$ melalui bantuan software SPSS (Statistic Product and Service Solutions) Statistic 20.

\section{Hasil dan Pembahasan}

\section{A. Hasil Penelitian}

\section{Analisis Statistik Deskriptif}

Analisis statistik deskriptif digunakan untuk menggambarkan peristiwa, perilaku atau objek tertentu lainnya dalam bentuk kuantitatif dengan tidak menyertakan pengambilan keputusan melalui hipotesis.

Tabel 1. Data Statistik deskriptif pretest dan posttest kelompok IMPROVE (metode pembelajaran IMPROVE) dan kelompok ekspositori (metode pembelajaran ekspositori).

\section{Kelompok Kelompok IMPROVE Ekspositori}

Statistik

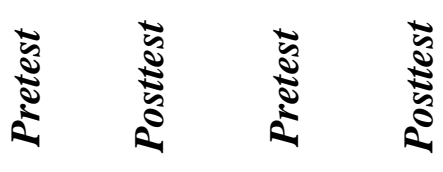

\begin{tabular}{ccccc}
\hline $\begin{array}{c}\text { Ukuran } \\
\text { sampel }\end{array}$ & 22 & 22 & 22 & 22 \\
\hline Rata-rata & 65 & 83,77 & 61,31 & 81 \\
\hline $\begin{array}{c}\text { Standar } \\
\text { deviasi }\end{array}$ & 9,03 & 2,65 & 9,18 & 3,65 \\
\hline $\begin{array}{c}\text { Nilai } \\
\text { terendah }\end{array}$ & 45 & 79 & 40 & 75 \\
\hline $\begin{array}{c}\text { Nilai } \\
\text { tertinggi }\end{array}$ & 77 & 89 & 78 & 92 \\
\hline
\end{tabular}

Tabel 2. Distribusi frekuensi dan persentase kategori nilai pretest dan postest 
kelompok IMPROVE dan kelompok besar perbedaan perubahan peningkatan ekspositori.

kemampuan pada kelas IMPROVE dan

\begin{tabular}{|c|c|c|c|c|c|c|c|c|}
\hline \multirow{3}{*}{ 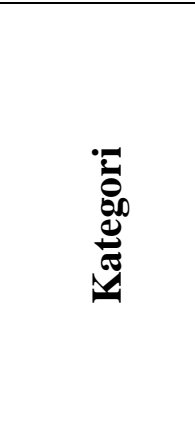 } & \multicolumn{4}{|c|}{ Kelas IMPROVE } & \multicolumn{4}{|c|}{ Kelas Ekspositori } \\
\hline & & 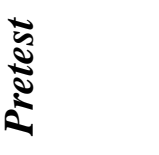 & & 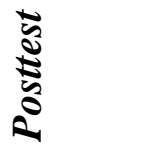 & & $\frac{\hbar}{5}$ & & 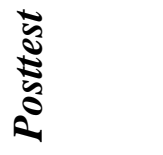 \\
\hline & $\mathrm{F}$ & 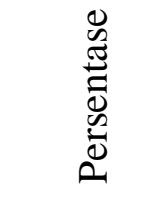 & $\mathrm{F}$ &  & $\mathrm{F}$ &  & $\mathrm{F}$ & 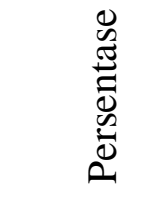 \\
\hline Amat Baik & 0 & $0,00 \%$ & 7 & $31,82 \%$ & 0 & $0,00 \%$ & 2 & $9,10 \%$ \\
\hline Baik & 8 & $36,36 \%$ & 15 & $68,18 \%$ & 3 & $13,64 \%$ & 20 & $90,90 \%$ \\
\hline Cukup & 11 & $50,00 \%$ & 0 & $0,00 \%$ & 19 & $86,36 \%$ & 0 & $0,00 \%$ \\
\hline Kurang & 3 & $13,64 \%$ & 0 & $0,00 \%$ & 0 & $0,00 \%$ & 0 & $0,00 \%$ \\
\hline Jumlah & 22 & $100 \%$ & 22 & $100 \%$ & 22 & $100 \%$ & 22 & $100 \%$ \\
\hline
\end{tabular}

Berdasarkan pada Tabel 1. tentang analisis deskriptif hasil penelitian maka dapat digambarkan nilai pretest di kedua kelas. Pada kelompok IMPROVE memperoleh nilai rata-rata 65 dan kelompok ekspositori memperoleh nilai rata-rata 61,31. Dengan kata lain kemampuan awal siswa pada kedua kelas tersebut nilai rata-ratanya hampir sama, sehingga dapat digunakan sebagai subjek penelitian.

Setelah diberikan perlakuan (treatment), nilai posttest di kedua kelompok yaitu kelompok IMPROVE dan kelompok ekspositori menunjukkan peningkatan. Pada kelompok IMPROVE memperoleh nilai rata-rata 83,77 sedangkan pada kelompok ekspositori memperoleh nilai rata-rata 81 dari skor maksimal yaitu 100.

Keseluruhan nilai yang diperoleh siswa juga dikelompokkan dalam pengkategorian hasil belajar. Frekuensi dan persentase kategori hasil belajar siswa pada kelompok IMPROVE dan kelompok ekspositori dapat dilihat pada tabel 2 .

Analisis gain ternormalisasi digunakan untuk mengetahui seberapa kelas ekspositori. Rata-rata gain ternormalisasi kelompok IMPROVE dan kelompok ekspositori dapat dilihat pada tabel 3 .

Tabel 3. Rata-rata N-gain kelompok berdasarkan metode pembelajaran

\begin{tabular}{ccc}
\hline Jenis Metode & $\begin{array}{c}\text { Rata-rata N- } \\
\text { Gain } \\
\text { Kelompok }\end{array}$ & Kategori \\
\hline $\begin{array}{c}\text { Metode } \\
\text { Pembelajaran } \\
\text { IMPROVE }\end{array}$ & 0,51 & Sedang \\
\hline $\begin{array}{c}\text { Metode } \\
\text { Pembelajaran } \\
\text { Ekspositori }\end{array}$ & 0,49 & Sedang \\
\hline
\end{tabular}

Berdasarkan data hasil analisis pada Tabel 3, maka dapat diketahui bahwa nilai rata-rata gain pada kelompok metode pembelajaran IMPROVE adalah 0.51. Nilai tersebut menunjukkan bahwa peningkatan pada kelompok metode pembelajaran IMPROVE berada pada kategori sedang. Hal yang sama ditunjukkan pada kelompok metode pembelajaran ekspositori yang menunjukkan nilai 0.49 yang artinya peningkatan pada kelompok metode pembelajaran ekspositori dikategorikan sedang. Data yang diperoleh dari kedua kelompok metode pembelajaran 
menunjukkan efektivitas berada di kategori yang sama yakni berada pada kategori sedang yang artinya kedua metode pembelajaran memiliki efektivitas yang sama apabila diterapkan dalam sebuah pembelajaran.

\section{Analisis Statistik Inferensial}

a. Uji Normalitas

Tabel 4. One-Sample KolmogorovSemirnov Test kelompok IMPROVE dan kelompok ekspositori

\begin{tabular}{cccc}
\hline & \multicolumn{3}{c}{ Kolmogorov-Semirnov } \\
\cline { 2 - 4 } & Statistic & df & Sig. \\
\hline Pretest & .112 & 44 & .200 \\
\hline Posttest & .118 & 44 & .145 \\
\hline Gain & .111 & 44 & .200 \\
\hline
\end{tabular}

Berdasarkan tabel 4 di atas bahwa hasil analisis uji normalitas untuk kedua kelompok menunjukkan bahwa hasil pretest memperoleh nilai sig.(2-tailed) 0,200 > 0,05 . Kemudian hasil posttest memperoleh nilai sig.(2-tailed) $0,145>0,05$. Dan hasil gain memperoleh nilai sig.(2-tailed) 0,200 > 0,05 . Dari hasil perolehan menunjukkan bahwa nilai signifikansi yang diperoleh dari pretest, posttest, dan gain adalah lebih besar dari 0,05 sehingga dapat disimpulkan bahwa data yang diperoleh berasal dari subjek yang terdistribusi secara normal.

b. Uji Homogenitas

Tabel 5. Levene's Test kelompok IMPROVE dan kelompok ekspositori

\begin{tabular}{lcr}
\hline & \multicolumn{2}{c}{$\begin{array}{c}\text { Levene's Test for Equality } \\
\text { of Variances }\end{array}$} \\
\cline { 2 - 3 } & F & Sig. \\
\hline Pretest & .002 & .965 \\
\hline Posttest &. .081 & .777 \\
\hline Gain & 1.233 & .273 \\
\hline
\end{tabular}

Berdasarkan tabel 5. setelah dilakukan pengujian data maka diperoleh nilai signifikansi $0,965>0,05$ untuk pretest, $0,777>0,05$ untuk posttest, dan $0,273>0,05$ untuk gain. Karena nilai signifikansi yang lebih dari 0,05 maka dapat disimpulkan bahwa kedua kelas homogen.

\section{c. Uji Hipotesis}

Tabel 6. Hasil Uji t kelompok IMPROVE dan kelompok ekspositori

\begin{tabular}{|c|c|c|c|}
\hline \multicolumn{4}{|c|}{ Independent Samples Test } \\
\hline & \multicolumn{3}{|c|}{ t-test for Equality Means } \\
\hline & $\mathrm{t}$ & df & Sig. (2-tailed) \\
\hline Pretest & -1.308 & 42 & .198 \\
\hline Posttest & -2.831 & 42 & .007 \\
\hline Gain & -793 & 42 & .43 \\
\hline $\begin{array}{l}\quad \text { Ber } \\
\text { hipotesis } \\
\text { signifikan } \\
\text { nilai sign } \\
\text { diterima } \\
\text { bahwa hif } \\
\text { tidak ter } \\
\text { biologi a } \\
\text { dengan } \mathrm{m} \\
\text { IMPROV }\end{array}$ & $\begin{array}{l}\text { arkan } \\
\text { menunju } \\
\text { dari gain } \\
\text { kansi } 0, \\
\mathrm{H}_{1} \text { ditol } \\
\text { esis pene } \\
\text { pat per } \\
\text { ara sisw } \\
\text { erapkan }\end{array}$ & $\begin{array}{l}\text { bel } \\
\text { kan } \\
\text { dalah } \\
2>0 \\
\text { x. Dapa } \\
\text { tian in } \\
\text { daan } \\
\text { yang } \\
\text { netode } \\
\text { wa yan }\end{array}$ & $\begin{array}{l}6, \text { pengujian } \\
\text { bahwa nilai } \\
0,432 . \text { Karena } \\
, 05 \text { maka } \mathrm{H}_{0}\end{array}$ \\
\hline
\end{tabular}

\section{B. Pembahasan}

Penelitian ini merupakan penelitian yang membandingkan hasil belajar biologi siswa materi pewarisan sifat antara siswa yang dibelajarkan dengan metode pembelajaran IMPROVE dan metode pembelajaran ekspositori pada kelas IX dengan berpedoman pada nilai Kriteria Ketuntasan Minimal (KKM) yang ditetapkan oleh MTsN 2 Majene. Nilai KKM MTsN 2 Majene mata pelajaran IPA adalah 83.

Pada kelas IMPROVE, siswa dibelajarkan dengan menggunakan metode pembelajaran ekspositori dan IMPROVE. Pembelajaran ini berlangsung selama empat kali pertemuan. Pada pertemuan pertama dan kedua, kelompok ini menggunakan metode pembelajaran ekspositori seperti kelompok ekspositori yaitu pada kegiatan awal dimulai dengan pemberian motivasi kepada siswa dengan memberikan sejumlah 
pertanyaan yang relevan dengan topik pelajaran sekaligus dapat menarik minat siswa untuk belajar. Pada kegiatan inti peneliti mengorganisasikan siswa untuk membentuk lima kelompok. Setelah itu siswa mengerjakan LKS secara berkelompok dengan bimbingan dari peneliti. Lalu perwakilan dari setiap kelompok memaparkan hasil kerja kelompoknya dan peneliti memberikan penghargaan bagi kelompok yang mendapatkan nilai tertinggi. Kemudian peneliti memberikan kuis untuk menguji pemahaman siswa. Di akhir kegiatan, siswa diberikan kesempatan untuk menyimpulkan pelajaran secara lisan.

Pertemuan ketiga dan keempat kelompok IMPROVE menggunakan metode pembelajaran IMPROVE. Kegiatan pembelajaran pada kelompok ini dimulai dengan pemberian motivasi kepada siswa dengan memberikan sejumlah pertanyaan yang relevan dengan topik pelajaran sekaligus dapat menarik minat siswa untuk belajar. Pada kegiatan inti peneliti menjelaskan masalah kontekstual mengenai konsep pewarisan sifat lalu memberikan contoh soal mengenai persilangan pada pewarisan sifat. Kemudian mengorganisasikan siswa untuk membentuk lima kelompok. Setelah itu siswa mengerjakan soal dan kartu metakognisi secara berkelompok dengan bimbingan dari peneliti. Lalu perwakilan dari setiap kelompok memaparkan hasil kerja kelompoknya dan peneliti mengevaluasi jawaban setiap kelompok. Selanjutnya peneliti memberikan penghargaan bagi kelompok yang mendapatkan nilai tertinggi. Kemudian peneliti memberikan kuis untuk menguji pemahaman siswa. Siswa yang berhasil mengerjakan soal kuis akan mendapatkan soal pengayaan sedangkan siswa yang belum berhasil mengerjakan soal kuis diminta untuk mengulang kembali materi di rumah. Apabila ada hal yang belum dipahami bisa ditanyakan kepada temannya atau peneliti pada pertemuan selanjutnya. Di akhir kegiatan, siswa diberikan kesempatan untuk menyimpulkan pelajaran secara lisan.

Hasil belajar sebelum dan setelah dibelajarkan dengan menggunakan metode pembelajaran IMPROVE menunjukkan adanya perbedaan. Siswa setelah dibelajarkan dengan menggunakan metode pembelajaran IMPROVE memiliki nilai rata-rata 83,77 yang masuk dalam kategori baik yang jika dibandingkan dengan hasil pretest siswa yang memiliki nilai rata-rata 65 yang masuk dalam kategori cukup. Dari perbedaan tersebut maka dapat terlihat bahwa hasil belajar siswa mengalami peningkatan setelah dibelajarkan dengan menggunakan metode pembelajaran IMPROVE.

Ada beberapa penelitian sebelumnya yang telah menggunakan metode pembelajaran IMPROVE dalam proses pembelajaran, diantaranya ialah Penelitian yang dilakukan oleh Liberna (2012) menunjukkan bahwa kemampuan berpikir kritis matematis siswa yang diajar dengan metode IMPROVE lebih tinggi dari pada dengan metode konvensional. Selanjutnya penelitian yang dilakukan oleh Laksono (2014) menunjukkan bahwa: pengelolaan pembelajaran oleh guru secara keseluruhan dapat dikategorikan baik; (2) siswa tergolong aktif selama pembelajaran dengan rata-rata persentase aktivitas siswa adalah $75,47 \%$, selanjutnya aktivitas siswa yang dominan adalah mendiskusikan permasalahan yang diberikan dengan anggota kelompok dan mengerjakan kuis secara individu; (3) nilai rata-rata hasil belajar siswa adalah 74,95; dan (4) respons siswa terhadap pembelajaran dengan metode IMPROVE adalah positif. Dan penelitian yang dilakukan oleh Afriani (2014) menunjukkan bahwa:

Kemampuan representasi matematis siswa yang mendapat pembelajaran menggunakan metode IMPROVE lebih baik daripada siswa yang mendapat pembelajaran secara konvensional; (2) Siswa menunjukkan respon positif terhadap pelajaran matematika dengan menggunakan metode 
IMPROVE. Berdasarkan dari tiga penelitian sebelumnya, dapat disimpulkan bahwa siswa menunjukkan respon positif terhadap pembelajaran yang menerapkan metode IMPROVE.

Adapun beberapa keunggulan metode IMPROVE yang dikemukakan oleh Mavarech (1997) ialah (1) mengarahkan siswa untuk menentukan sendiri cara yang akan digunakan untuk menyelesaikan soalsoal melalui pertanyaan-pertanyaan metakognisi yang tercantum dalam kartu metakognisi; (2) melakukan pengayaan bagi siswa agar materi yang telah dipelajari dapat dipahami secara mendalam.

Pada kelompok selanjutnya yaitu kelompok ekspositori, siswa dibelajarkan dengan menggunakan metode pembelajaran ekspositori. Pembelajaran ini berlangsung selama empat kali pertemuan. Pada kegiatan awal dimulai dengan pemberian motivasi kepada siswa dengan memberikan sejumlah pertanyaan yang relevan dengan topik pelajaran sekaligus dapat menarik minat siswa untuk belajar. Pada kegiatan inti peneliti mengorganisasikan siswa untuk membentuk lima kelompok. Setelah itu siswa mengerjakan LKS secara berkelompok dengan bimbingan dari peneliti. Lalu perwakilan dari setiap kelompok memaparkan hasil kerja kelompoknya dan peneliti memberikan penghargaan bagi kelompok yang mendapatkan nilai tertinggi. Kemudian peneliti memberikan kuis untuk menguji pemahaman siswa. Di akhir kegiatan, siswa diberikan kesempatan untuk menyimpulkan pelajaran secara lisan.

Hasil belajar sebelum dan setelah dibelajarkan dengan menggunakan metode pembelajaran ekspositori menunjukkan adanya perbedaan. Perbedaan tersebut terlihat pada hasil belajar siswa setelah dibelajarkan dengan menggunakan metode pembelajaran ekspositori memiliki nilai rata-rata 81 dan masuk dalam kategori baik. Apabila dibandingkan dengan hasil pretest siswa yang memiliki nilai rata-rata 61,31 yang masuk dalam kategori cukup maka terlihat bahwa hasil belajar siswa mengalami peningkatan setelah dibelajarkan dengan menggunakan metode pembelajaran ekspositori.

Ada beberapa kelemahan dari metode pembelajaran ekspositori. Menurut Riadi (2013) ialah (1) metode pembelajaran ini hanya mungkin dapat dilakukan terhadap siswa yang memiliki kemampuan mendengar dan menyimak secara baik; (2) metode ini tidak mungkin dapat melayani perbedaan setiap individu baik perbedaan kemampuan, pengetahuan, minat, dan bakat, serta perbedaan gaya belajar siswa; (3) metode ini sulit mengembangkan kemampuan siswa dalam hal kemampuan sosialisasi, hubungan interpersonal, serta kemampuan berpikir kritis; (4) keberhasilan metode pembelajaran ekspositori sangat tergantung kepada apa yang dimiliki guru, seperti persiapan, pengetahuan, rasa percaya diri, semangat, antusiasme, motivasi, dan kemampuan mengelola kelas. Tanpa itu sudah dipastikan pembelajaran tidak mungkin berhasil; (5) pengetahuan yang dimiliki siswa akan terbatas pada apa yang diberikan guru mengingat gaya komunikasi metode pembelajaran ini lebih banyak terjadi satu arah (one-way communication). Sehingga kesempatan untuk mengontrol pemahaman siswa akan terbatas pula.

Analisis data dengan menggunakan teknik analisis statistik inferensial untuk menguji hipotesis penelitian dengan menggunakan SPSS versi 20.00, nilai signifikansi yang diperoleh adalah 0,432 > 0,05 . Hal ini menunjukkan bahwa tidak terdapat perbedaan hasil belajar biologi yang signifikan antara siswa yang dibelajarkan dengan menerapkan metode pembelajaran IMPROVE dengan metode pembelajaran ekspositori pada materi pewarisan sifat kelas IX sehingga hipotesis penelitian ini ditolak.

Ada beberapa hal yang memengaruhi hasil penelitian sehingga hipotesisnya ditolak. Salah satunya ialah waktu yang digunakan saat menerapkan metode 
IMPROVE di kelas cukup singkat. Hal ini menyebabkan tidak optimalnya penerapan metode IMPROVE pada setiap fase yang telah tercantum pada Rancangan Pelaksanaan Pembelajaran (RPP). Selain itu, peneliti juga tidak sempat untuk memberikan bimbingan yang lebih pada siswa yang memiliki kemampuan pemecahan masalah dibawah rata-rata. Faktor selanjutnya ialah siswa tidak terbiasa melakukan proses pembelajaran dengan menggunakan metode baru dalam hal ini metode IMPROVE sehingga siswa perlu waktu untuk menyesuaikan diri dengan metode pembelajaran ini.

Hasil belajar yang didapatkan oleh siswa mengalami peningkatan yang cukup rendah. Faktor yang menyebabkan pretest siswa yang cukup tinggi ialah karena guru yang selalu menghimbau siswanya pada pertemuan sebelum memasuki materi baru agar mempelajari materi pelajaran selanjutnya. Hal ini menyebabkan siswa yang mengikuti pretest telah memiliki pengetahuan awal mengenai materi pewarisan sifat sehingga peningkatan nilainya tidak terlalu signifikan apabila posttest dibandingkan dengan pretest masing-masing kelas.

Peneliti tidak memungkiri bahwa faktor lain selain metode pembelajaran turut mempengaruhi hasil belajar yang diperoleh siswa pada kedua kelompok, misalnya faktor yang tidak bisa direkayasa oleh peneliti seperti faktor intelegensi, kesiapan siswa, kesehatan, maupun lingkungan sosial siswa sehingga peningkatan yang terjadi masih berada pada kisaran sedang dengan masih ada siswa yang berada pada kategori rendah.

Hasil belajar atau prestasi belajar bukanlah hal yang berdiri sendiri, tetapi merupakan hasil dari berbagai faktor yang melatarbelakanginya. Faktor utama yaitu faktor dari diri siswa terutama kemampuan yang dimiliki dan faktor dari lingkungan. Selain faktor utama yang telah disebutkan sebelumnya, faktor lain yang tak kalah pentingnya adalah motivasi, minat, perhatian, sikap belajar, faktor fisik dan psikis. Meskipun demikian hasil belajar yang diperoleh masih juga dipengaruhi oleh lingkungan. Salah satu yang paling mempengaruhi adalah kualitas pengajaran. Kualitas pengajaran yang dimaksudkan disini adalah efektif tidaknya proses belajar mengajar dalam mencapai tujuan pembelajaran. Hal tersebut sejalan dengan teori belajar di sekolah dari Bloom dalam Sabri (2010) yang mengatakan ada tiga variabel utama dalam teori belajar di sekolah yaitu karakteristik individu, kualitas pengajaran dan hasil belajar siswa. Kemampuan siswa dan kualitas pengajaran berbanding lurus dengan hasil belajar. Artinya, makin tinggi kemampuan siswa dan kualitas pengajaran, makin tinggi pula hasil belajar siswa. Oleh sebab itu, guru harus pandai mengelola pembelajaran dengan mempertimbangkan faktor-faktor di atas, sehingga prestasi atau hasil belajar siswa dapat mencapai hasil yang optimal.

\section{Simpulan}

Berdasarkan hasil analisis data dan pembahasan yang telah dikemukakan di atas, maka dapat disimpulkan sebagai berikut:

1. Hasil belajar biologi materi pewarisan sifat siswa yang dibelajarkan dengan menerapkan metode pembelajaran IMPROVE pada kelas IX MTsN 2 Majene berada pada kategori baik.

2. Hasil belajar biologi materi pewarisan sifat siswa yang dibelajarkan dengan menerapkan metode pembelajaran ekspositori pada kelas IX MTsN 2 Majene berada pada kategori baik.

3. Tidak ada perbedaan hasil belajar biologi materi pewarisan sifat siswa yang dibelajarkan dengan menerapkan metode pembelajaran IMPROVE dan ekspositori pada kelas IX MTsN 2 Majene.

\section{Daftar Pustaka}

[1] Afriani, Nur Fitri Siti. 2014. Pengaruh Pembelajaran Matematika dengan Metode IMPROVE terhadap 
Kemampuan Representasi Matematis Siswa SMP. Skripsi. Bandung: Fakultas Pendidikan Matematika dan Ilmu Pengetahuan Alam. Tersedia di http://repository.upi.edu/6757/

[2] Aurah, Catherine Muhonja, et al. 2014. Genetics Problem Solving in High School Testing in Kenya: Effects of Metacognitive Prompting During Testing. Electronic Journal of Science Education Vol. 18 No. 8.

[3] Laksono, Retnaning Putri dan Susanah. 2014. Penerapan Pembelajaran Dengan Metode IMPROVE pada Materi Pertidaksamaan di Kelas X-B SMAN 1 Kauman Tulungagung. Jurnal Ilmiah Pendidikan Matematika Volume 3 No 2 Tahun 2014. Tersedia di http://ejournal.unesa.ac.id/article/11685/30 larticle.pdf

[4] Liberna, Hawa. 2012. Peningkatan Kemampuan Berpikir Kritis Matematis Siswa Melalui Penggunaan Metode IMPROVE pada Materi Sistem Persamaan Linear Dua Variabel. Jurnal Formatif 2(3): 190-197. Tersedia di http://journal.lppmunindra.ac.id/index.php/ Formatif/article/view/101/96

[5] Mevarech, Zemira., dan Kramarski, Brancha. 1997. IMPROVE: A Multidimensional Method for Teaching Mathematics in Heterogeneous Classroom. American Educational Research Journal 34(2):365-394. Tersedia di http://aer.sagepub.com/ content/34/2/365.full.pdf

[6] Riadi, Muchlisin. 2013. Metode Belajar Ekspositori. Kajian Pustaka. Tersedia di http://www.kajianpustaka.com/2012/ 12/metode-belajar-ekspositori.html

[7] Sabri, Ahmad. 2010. Strategi Belajar Mengajar dan Micro Teaching. Padang: PT.Ciputat Press.

[8] Yuningsih, Dewi. 2010. Penerapan Metode Pembelajaran IMPROVE Untuk Meningkatkan Hasil Belajar Siswa Dalam Pembelajaran Teknologi Informasi Dan Komunikasi (TIK). Skripsi. Universitas Pendidikan Bandung.

\section{Profil Penulis}

Firdaus lahir di Kota Parepare pada tahun 1991. Pendidikan sarjana diselesaikan di Program Studi Pendidikan Biologi ICP Universitas Negeri Makassar pada tahun 2014. Pendidikan magister diselesaikan di Fakultas Biologi (Peminatan Genetika dan Biologi Molekuler) Universitas Gadjah Mada pada tahun 2016. Saat ini, merupakan Dosen Pendidikan Biologi di Universitas Sulawesi Barat.

Rasydianah lahir di Kota Palopo pada tahun 1994. Pendidikan sarjana diselesaikan di Program Studi Pendidikan Biologi ICP Universitas Neg 

